\title{
Thomasaria vs. Pyramidalia conundrum in Devonian brachiopod systematics solved: An argument to formalize epitypification under the ICZN
}

\author{
Adam T. Halamski and Andrzej Baliński \\ Acta Palaeontologica Polonica 64 (2), 2019: 399-408 doi:https://doi.org/10.4202/app.00603.2019
}

Pyramidalia is a brachiopod genus with Spirifera simplex as the type species. Imprecise diagnosis and misidentification of the material studied in the original description resulted in a plethora of interpretations (a valid genus belonging either to the order Spiriferida or to the Spiriferinida; synonym of the spiriferide Thomasaria; synonym of Squamulariina or Cyrtinaella, both spiriferinides). To address this problem we designated the specimen GSM 6915 from Wolborough quarry near Newton Abbot (Devon, England; Givetian) as the lectotype of Spirifera simplex . We examined microstructure and internal characters of a topotypic specimen and found out that Spirifera simplex has an impunctate shell and is thus a spiriferide, not a spiriferinide. No significant differences in morphology or internal characters of Thomasaria and Pyramidalia can be found, so the latter is interpreted as a junior subjective synonym of the former. The procedure used in the present analysis is equivalent to the epitypification provided for in the ICN; formalisation of a similar procedure under the ICZN is recommended.

Key words: Brachiopoda, Pyramidalia, Thomasaria, epitypification, ICZN, Devonian, UK, England.

Adam T. Halamski [ath@twarda.pan.pl] and Andrzej Baliński [balinski@twarda.pan.pl], Institute of Paleobiology, Polish Academy of Sciences, ul. Twarda 51/55, 00-818 Warszawa, Poland.

This is an open-access article distributed under the terms of the Creative Commons Attribution License (for details please see creativecommons.org), which permits unrestricted use, distribution, and reproduction in any medium, provided the original author and source are credited. 
FaF Full text $(688.2 \mathrm{kB})$ 